\title{
Selection and characterization of Beauveria spp. isolates to control the broad mite Polyphagotarsonemus latus (Banks, 1904) (Acari: Tarsonemidae)
}

\author{
C. C. Martins ${ }^{a}$, L. F. A. Alves ${ }^{*}$, A. P. Mamprim ${ }^{a}$ and L. P. A. Souza ${ }^{a}$ \\ aPrograma de Pós-graduação em Conservação e Manejo de Recursos Naturais, Laboratório de Biotecnologia Agrícola, \\ Universidade Estadual do Oeste do Paraná - Unioeste, Rua Universitária, 2069, Jardim Universitário, \\ CEP 85819-110, Cascavel, PR, Brazil \\ *e-mail: luis.alves@unioeste.br
}

Received: October 29, 2014 - Accepted: June 17, 2015 - Distributed: August 31, 2016

(With 1 figure)

\begin{abstract}
This study was performed under laboratory conditions to identify isolates of the fungus Beauveria spp. that can control Polyphagotarsonemus latus in the greenhouse and field. Thirty Beauveria spp. isolates were tested by spraying $1 \mathrm{~mL}$ conidia $\left(1 \times 10^{8}\right.$ conidia $\left./ \mathrm{mL}\right)$ on pepper leaf discs containing 15 mites. Evaluations were performed on the 3rd and 6th day post application by counting the number of dead mites. Vegetative growth and conidial production were measured from the selected isolates, and bioassays were conducted in the greenhouse on bean seedlings in plastic pots. The isolate Unioeste 53 was selected, and a conidial suspension $\left(1 \times 10^{8}\right.$ conidia $\left./ \mathrm{mL}\right)$ was applied with a backpack sprayer. The evaluation consisted of pre- and post-treatment counts of the number of live mites on ten leaflets in both the plots treated with the fungus and control plots, and the same procedure was followed for the field experiment. In the laboratory, the Unioeste 53 isolate resulted in total and confirmed mortality rates of $70 \%$ and $57.7 \%$, respectively. In the greenhouse, the population decreased by $76.71 \%$ by the 16 th day after application. In the field, the population decreased by $66 \%$ by the 12 th day after application, demonstrating the potential of this fungus for mite management.
\end{abstract}

Keywords: microbial control, entomopathogenic fungi, broad mite.

\section{Seleção e caracterização de isolados do fungo Beauveria spp. visando ao controle do ácaro branco Polyphagotarsonemus latus (Banks, 1904) (Acari: Tarsonemidae)}

\section{Resumo}

Este trabalho teve por objetivo selecionar isolados do fungo Beauveria bassiana em condições de laboratório com potencial de uso em casa de vegetação e campo no controle do ácaro branco. Foi realizada uma seleção com 30 isolados de Beauveria spp. através de pulverização direta de conídios $\left(1 \times 10^{8}\right.$ conídios $\left./ \mathrm{mL}\right)$ sobre discos foliares de pimenta contendo 15 ácaros. As avaliações foram realizadas no terceiro e sexto dia contando-se o número de mortos, e confirmação do patógeno em câmara úmida. Parâmetros de crescimento vegetativo e produção de conídios foram avaliados. No bioensaio em casa de vegetação foram preparados vasos com plantas de feijão e fez-se a aplicação do Unioeste $53\left(1 \times 10^{8}\right.$ conídios $\left./ \mathrm{mL}\right)$, utilizando pulverizador costal, a avaliação constou da contagem prévia e posterior à aplicação do número de ácaros vivos em 10 folíolos, tanto nas parcelas destinadas ao tratamento com fungo, quanto na testemunha. A fase de campo seguiu os mesmos padrões, porém, com área experimental total de $225 \mathrm{~m}^{2}$, com oito parcelas de 10,24 $\mathrm{m}^{2}$, sendo 4 testemunhas e 4 onde foi aplicado o isolado Unioeste 53 seguindo metodologia de aplicação e avaliação já descritas para casa de vegetação. Em laboratório o isolado Unioeste 53 causou mortalidade total de $70 \%$ e $57,7 \%$ de mortalidade confirmada. Em casa de vegetação, apresentou redução da população de $76,71 \%$ 16 dias após aplicação, já em campo, a redução da população foi de $66 \%$ após 12 dias da aplicação, demonstrando o potencial do ácaro pelo fungo.

Palavras-chave: controle microbiano, fungos entomopatogênicos, ácaro branco. 


\section{Introduction}

The broad mite Polyphagotarsonemus latus (Banks, 1904) (Acari: Tarsonemidae) is one of the most important species of phytophagous mites, and it is a cosmopolitan and polyphagous pest associated with various crops (Moraes and Flechtmann, 2008; Sarmento et al., 2011).

This pest damages crops by perforating the plant cell wall, which results in the leakage of intracellular contents, upon which the pest feeds. Breakage of the cell wall can lead to uneven leaf growth, decreased photosynthetic capacity and early leaf drop, which affects plant development and yield and provides a gateway for opportunistic pathogenic microorganisms (Moraes and Flechtmann, 2008; Alves et al., 2010).

Synthetic chemical acaricides are commonly used to control mite populations; however, improper chemical use has negative effects, including intoxication at the time of application and the presence of residues in food. In addition, these products can result in mite populations resistant to the active ingredients and can eliminate non-target organisms, thus affecting natural enemies and even vertebrates depending on the concentration and exposure time (Gallo et al., 2002; Alves et al., 2008).

The control of this mite becomes more difficult when $P$. latus attacks crops for which there are no registered chemical acaricides, such as yerba mate. This mite has been cited as a significant pest in yerba mate nurseries and can severely damage seedlings, which then become unviable for planting (Alves et al., 2010; BRASIL, 2012). The use of chemical acaricides is restricted to organic and agro-ecological farming, especially for crops that co-occur with $P$. latus and are fairly common on small farms, thus representing a large share of the income of small producers (Echer et al., 2002).

Within the context of natural resource conservation and management, studies have been conducted to reduce the impact of phytophagous mites on the environment and human health and develop alternatives for controlling such populations. Entomopathogenic fungi have produced positive results in the control of P. latus, and studies in the laboratory and greenhouses have demonstrated the potential of entomopathogenic fungi, particularly Beauveria bassiana, against this mite species (Peña et al., 1996; Nugroho and Ibrahim, 2007; Alves et al., 2010). However, field studies on using entomopathogenic fungi to control mites are scarce and non-existent for P. latus.

Because of the potential of B. bassiana for mite control, the objective of this study was to select, characterize and evaluate potential isolates of the fungus Beauveria spp. from Brazil for use in the control of the broad mite P. latus in the greenhouse and field.

\section{Material and Methods}

This study was conducted in three phases. The first phase was conducted in the laboratory, the second phase was conducted in a greenhouse, and the third phase was conducted in the field in the municipality of Marechal
Cândido Rondon, PR, São Cristóvão (24³9'19.96 “S, $54^{\circ} 01^{\prime} 08.66^{\prime}$ 'W, $302 \mathrm{~m}$ altitude) from January to March 2014.

\subsection{Fungal isolates}

Thirty isolates were obtained from the entomopathogenic fungi collection of the Unioeste Agricultural Biotechnology Laboratory - Cascavel Campus, PR (UNIOESTE, 2014), where these fungi are stored as pure conidia derived from monosporic cultures and maintained at $-80{ }^{\circ} \mathrm{C}$ (Table 1).

The isolates were inoculated over seven days on Petri dishes containing a sporulation culture medium (SM) to produce conidia (20 g agar, $5 \mathrm{~g}$ yeast extract, $4.6 \mathrm{~g}$ salt mixture, $10 \mathrm{~g}$ glucose and $1000 \mathrm{~mL}$ distilled water) and incubated at $26 \pm 1{ }^{\circ} \mathrm{C}$ with 14 hours of photophase. The conidia were then scraped from the surface of the culture medium and stored in sterile glass tubes that were closed and stored for a period not exceeding 15 days at $-10{ }^{\circ} \mathrm{C}$ for later use in bioassays (Alves et al., 1998).

\subsection{Source of mites}

Mites of the species P. latus were obtained from mulberry trees (Morus alba L.) (Malvales: Moraceae). Mite identification was performed according to and Moraes and Flechtmann (2008) by fixing specimens and observing them under a microscope.

The mites were reared on Balloon pepper plants (Capsicum baccatum L.) (Solanales: Solanaceae) in pots and maintained in a greenhouse. When the leaves became wrinkled, new pepper seedlings were introduced into the stock for infestation (Echer et al., 2002).

\subsection{Selection of isolates}

The selection of the isolates was based on a study by Oliveira et al. (2004). Beauveria spp. strains were grown on artificial media as described above to produce the inoculum. The conidia were scraped and transferred into glass tubes to which distilled water $+0.01 \%$ Tween 80 was added. The suspensions were counted in a Neubauer chamber and then standardized to $1 \times 10^{8}$ conidia $/ \mathrm{mL}$. The isolates had a minimum viability of $90 \%$, which was verified on artificial media as described by Alves et al. (1998).

In the preparation of bioassays, $226 \mathrm{~mm}^{2}$ leaf discs were cut using a stainless steel punch. The discs were surrounded with moistened cotton and kept in Petri dishes that were lined with moistened foam with the abaxial side facing up, and they received ten female P. latus (Moraes and Flechtmann, 2008). The experimental design was completely randomized. For each isolate, three Petri dishes with three discs containing ten mite females were prepared for a total of 90 mites/treatment. Each plate was considered a replicate.

A suspension with $1 \mathrm{~mL}$ volume of the $1 \times 10^{8}$ conidia $/ \mathrm{mL}$ was sprayed on each leaf disc using a Potter spray tower (Burkard Agronomics, Uxbridge, Middlesex, United Kingdom) $\left(0.703 \mathrm{kgf} / \mathrm{cm}^{2}\right)$. Only sterile distilled water + $0.01 \%$ Tween 80 was sprayed on the controls. After spraying, the plates were incubated $\left(26 \pm 1{ }^{\circ} \mathrm{C}\right.$ at $70 \pm 10 \% \mathrm{RH}$ for a 14-hour photoperiod). The evaluation was performed on 
Table 1. Isolates of Beauveria spp. and respective hosts and places of origin.

\begin{tabular}{|c|c|c|c|}
\hline ISOLATE & SPECIES & HOST & LOCATION \\
\hline Unioeste 1 & Beauveria bassiana & Astylus variegatus (Coleoptera, Chrysomelidae) & Cascavel, PR \\
\hline Unioeste 2 & Beauveria sp. & $\begin{array}{l}\text { Alphitobius diaperinus } \\
\text { (Coleoptera, Tenebrionidae) }\end{array}$ & Cascavel, PR \\
\hline Unioeste 4 & Beauveria sp. & $\begin{array}{l}\text { Alphitobius diaperinus } \\
\text { (Coleoptera, Tenebrionidae) }\end{array}$ & Cascavel, PR \\
\hline Unioeste 5 & Beauveria sp. & $\begin{array}{l}\text { Alphitobius diaperinus } \\
\text { (Coleoptera, Tenebrionidae) }\end{array}$ & Cascavel, PR \\
\hline Unioeste 25 & Beauveria bassiana & Soil, Yerba mate plantation & Cascavel, PR \\
\hline Unioeste 26 & Beauveria bassiana & Soil, Yerba mate plantation & Cascavel, PR \\
\hline Unioeste 36 & Beauveria bassiana & Chrysomelidae sp. & Cascavel, PR \\
\hline Unioeste 37 & Beauveria bassiana & Bombyx mori (Lepidoptera: Bombycidae) & Arapongas, PR \\
\hline Unioeste 38 & Beauveria bassiana & Bombyx mori (Lepidoptera: Bombycidae) & Ibaiti, PR \\
\hline Unioeste 39 & Beauveria bassiana & $\begin{array}{l}\text { Cosmopolites sordidus (Coleoptera, } \\
\text { Curculionidae) }\end{array}$ & São Miguel do Iguaçu, PR \\
\hline Unioeste 40 & Beauveria bassiana & Curculionidae sp. & Cascavel, PR \\
\hline Unioeste 41 & Beauveria bassiana & Astylus variegatus (Coleoptera, Chrysomelidae) & Cascavel, PR \\
\hline Unioeste 42 & Beauveria bassiana & Erotylidae sp. & Cascavel, PR \\
\hline Unioeste 44 & Beauveria bassiana & Pentatomidae sp. & Toledo, PR \\
\hline Unioeste 46 & Beauveria bassiana & Euschistus heros & Cascavel, PR \\
\hline Unioeste 47 & Beauveria bassiana & Pentatomidae sp. & Primavera do Leste, MT \\
\hline Unioeste 48 & Beauveria sp. & $\begin{array}{l}\text { Alphitobius diaperinus } \\
\text { (Coleoptera, Tenebrionidae) }\end{array}$ & Cascavel, PR \\
\hline Unioeste 49 & Beauveria bassiana & $\begin{array}{l}\text { Alphitobius diaperinus } \\
\text { (Coleoptera, Tenebrionidae) }\end{array}$ & Cascavel, PR \\
\hline Unioeste 53 & Beauveria bassiana & $\begin{array}{l}\text { Alphitobius diaperinus } \\
\text { (Coleoptera, Tenebrionidae) }\end{array}$ & Cascavel, PR \\
\hline Unioeste 54 & Beauveria bassiana & $\begin{array}{l}\text { Alphitobius diaperinus } \\
\text { (Coleoptera, Tenebrionidae) }\end{array}$ & Cascavel, PR \\
\hline Unioeste 56 & Beauveria bassiana & Anthonomus grandis (Coleoptera, Curculionidae) & Cascavel, PR \\
\hline Unioeste 65 & Beauveria bassiana & Anthonomus grandis (Coleoptera, Curculionidae) & Cascavel, PR \\
\hline Unioeste 66 & Beauveria bassiana & Anthonomus grandis (Coleoptera, Curculionidae) & Cascavel, PR \\
\hline Unioeste 68 & Beauveria sp. & $\begin{array}{l}\text { Alphitobius diaperinus (Coleoptera, } \\
\text { Tenebrionidae) }\end{array}$ & Pinhalzinho, SP \\
\hline Unioeste 69 & Beauveria sp. & $\begin{array}{l}\text { Hedypathes betulinus (Coleoptera, } \\
\text { Cerambycidae) }\end{array}$ & Ivai, PR \\
\hline Unioeste 70 & Beauveria bassiana & Vatiga manihotae (Hemiptera, Tingidae) & Marechal C. Rondon, PR \\
\hline Unioeste 71 & Beauveria bassiana & Bemisia tuberculata (Hemiptera, Aleyrodidae) & Marechal C. Rondon, PR \\
\hline Unioeste 75 & Beauveria bassiana & Vatiga manihotae (Hemiptera, Tingidae) & Marechal C. Rondon, PR \\
\hline Unioeste 76 & Beauveria bassiana & Diabrotica speciosa (Coleoptera, Chrysomelidae) & Marechal C. Rondon, PR \\
\hline Unioeste 77 & Beauveria bassiana & Aphid collected on brassicas & Marechal C. Rondon, PR \\
\hline
\end{tabular}

the 3rd and 6th day after fungus application, and dead mites were transferred to a humid chamber for conidiogenesis. The cadavers were examined using a stereoscopic microscope $(250 \times$ magnification $)$ for signs of the fungus according to Humber (1997).

The data for the total and confirmed percent mortality at six days after application (DAA) was analyzed using descriptive statistics and plotted using Microsoft Excel. Isolates were selected based on their total and confirmed percentage of mortality values (minimum 50\%), and the confirmed mortality on the 3rd day was also determined for these isolates.

The data were analyzed for normality with the Shapiro-Wilk test, and data homogeneity was assessed using the Levene test with the program Statistics 7.0. When the results were homogeneous and normally distributed, an analysis of variance (ANOVA) and Tukey test $(\mathrm{p}<0.05)$ were used. At the end of the experiment, the isolate that presented the highest total and confirmed mortality was selected for field trials. This experiment was repeated twice, and the same tendency was observed in the results. 


\subsection{Vegetative growth and conidial production}

The selected isolates were characterized by evaluating their vegetative growth and conidial production in a culture medium and on commercial whole white rice.

Vegetative growth was evaluated by growing the isolates on a PDA (potato, dextrose, agar) medium in Petri dishes. A platinum needle was used to inoculate thee equidistant points on the surface of the culture medium. Next, plates were incubated for seven days at $26 \pm 1{ }^{\circ} \mathrm{C}$ and a 14-hour photoperiod. Subsequently, the colonies were measured (two perpendicular measurements) to obtain the mean colony diameter and area (Alves et al., 1998). For each isolate, four plates were prepared (each plate was considered a replicate). This experiment was repeated twice, and the same tendency was observed in the results.

After the vegetative growth evaluation, two colonies from each plate that exhibited uniform and homogeneous growth were selected to estimate the number of conidia per colony and per $\mathrm{cm}^{2}$. The colonies were cut from the medium along the borders and individually transferred to sterile glass tubes to which $10 \mathrm{~mL}$ distilled water containing $0.01 \%$ Tween 80 was added and stirred until the conidia were released. Serial dilutions were performed, and conidia were counted in a Neubauer chamber. Four plates with two colonies were used for each isolate. Each plate was considered a replicate. The average production of conidia was calculated in each plate according to the arithmetic mean of the conidial counts of both colonies. To estimate the conidial production per $\mathrm{cm}^{2}$, the total production of the colony was divided by its area.

Conidial production in rice was performed according to Alves and Faria (2010) with a completely randomized experimental design in which polypropylene bags were filled with $100 \mathrm{~g}$ commercial whole white rice and $40 \mathrm{~mL}$ distilled water, the mixture was homogenized manually, and the bags were then autoclaved for $30 \mathrm{~min}$ at $121^{\circ} \mathrm{C}$. After cooling, $10 \mathrm{~mL}$ conidial suspension $\left(1 \times 10^{8}\right.$ conidia $\left./ \mathrm{mL}\right)$ was added to the mixture in the bags. The bags were then incubated for ten days ( $26 \pm 1{ }^{\circ} \mathrm{C}$ over a 14 -hour photoperiod) and stirred daily to prevent the formation of clumps. Five bags were prepared for each isolate (each bag was considered a replicate). After ten days, the cultures were evaluated by removing $1 \mathrm{~g}$ of the rice + conidia mixture from each bag. Each sample was suspended in $10 \mathrm{~mL}$ distilled water $+0.01 \%$ Tween 80 . Serial dilutions and conidial counts were performed as previously descried to estimate the number of conidia per $g$ rice.

The normality of the data was verified using the Shapiro-Wilk test, and the homogeneity was verified by the Levene test. The data were analyzed using the Kruskal-Wallis test and the Student-Newman-Keuls test for post hoc comparison of means using the program BioEstat 5.3.

\subsection{Greenhouse experiment}

The greenhouse experiment conducted on bean seedlings (Phaseolus vulgaris L., Tiziu variety) occurred in a plastic container with potting soil. When the seedlings reached
$20 \mathrm{~cm}$ in height and had at least six leaves, the seedlings were subjected to mass broad mite rearing.

The fungus was multiplied once more on rice (Alves and Faria, 2010), and an emulsifiable oil formulation (provided by Novozymes BioAg S.A.) was prepared according to Oliveira (2009). The formulation was suspended in water $\left(1 \times 10^{8}\right.$ conidia $\left./ \mathrm{mL}\right)$ and applied using a backpack sprayer at a volume equivalent to $800 \mathrm{~L} / \mathrm{ha}$ on the adaxial and abaxial surfaces of the leaves in consideration of the habits of the mite and vegetation cover. In the control, distilled water + Tween $800.01 \%$ was applied.

The experimental design included completely randomized blocks. The data were analyzed by an ANOVA in a split-split plot in time design, with fungal presence/absence as the principal factor and time of evaluation as the secondary factor (before and 1,2,3 and 4 DAA). For each treatment, 50 pots with two plants were prepared. The pots were randomly distributed in five plots for each treatment (10 pots per plot) of distilled water (control) and Unioeste 53 isolate conidial suspension. The experiment was conducted in a randomly arranged split-plot in time design.

Prior to application, the mite population on the plants was assessed by randomly collecting ten leaves from each plot and counting the number of mites. This procedure was repeated at four, eight, 12 and 16 days after the fungal application.

The data were analyzed for normality with the Shapiro-Wilk test, and data homogeneity was assessed using the Levene test. When the results were homogeneous and normally distributed, an ANOVA and Tukey test $(p>0.05)$ were performed using the program Statistics 7.0.

\subsection{Field experiment}

The experimental area $\left(225 \mathrm{~m}^{2}\right)$ was divided into eight plots of $10.24 \mathrm{~m}^{2}$ and randomly distributed with bean plants over eight rows $\times$ eight columns as described by Emater (2000). Only the plants in the inner seven rows and seven columns were considered in the experiment. The plots were isolated using plastic sheeting to prevent drift during the fungal spraying. The experimental design was the same as for the greenhouse experiment. The $B$. bassiana Unioeste 53 isolate was applied to four plots (treatment), and water was applied to the other four plots (controls).

The plot infestation, production, fungal application and pre- and post-application evaluations were performed as described for the greenhouse experiment. This experiment was also conducted in a randomly arranged split-plot in time design.

The data were analyzed for normality with the Shapiro-Wilk test, and data homogeneity was assessed using the Levene test. The data were analyzed with the Wilcoxon test, and the mean number of mites on the treated and non-treated plants was compared. The data from different evaluation intervals were analyzed using the Friedman test $(\mathrm{p}<0.05)$ (Statistics 7.0).

The efficiency of the treatment for the field experiment was calculated using Henderson \& Tilton's formula (Bakr, 2002; Equation 1): 
$100 \times\{1-[(\mathrm{Cb} \times \mathrm{Ta}) \div(\mathrm{Ca} \times \mathrm{Tb})]\}$

where $\mathrm{Tb}$ and $\mathrm{Ta}$ represent the mean mite lifespan in the treatment group before and after treatment and $\mathrm{Cb}$ and $\mathrm{Ca}$ represent the mean mite lifespan in the control group before and after treatment.

\section{Results and Discussion}

\subsection{Selection of isolates}

The total mite mortality ranged from 0 to $82 \%$, and a large variation was observed among the isolates. The confirmed mortality percentages were generally as low as $40 \%$ and varied among the isolates. Variation between the total and confirmed mortality values for the same isolate is quite common and may occur for many reasons (Figure 1). One of these reasons is that the fungus often causes death, but this cannot always be confirmed because the host may die from mechanical damage, such as by perforation of the integument or vital organs, or indirectly because of fungal growth leading to the production of toxins and the depletion of nutrients. Additionally, the fungus does not always encounter suitable conditions to complete its life cycle (Hajek and St. Leger, 1994; Alves, 1998).

Thus, a minimum confirmation of $50 \%$ at 6 DAA was used to select the Unioeste 26, Unioeste 53 and Unioeste 39 isolates (Figure 1). In addition, a comparison of the mortality values at 3 DAA showed that the greatest efficiency was exhibited by isolated Unioeste 53 at $33 \%$ mortality. Thus, Unioeste 53 was selected for the greenhouse and field experiments (Table 2).

The selection of isolates is the first step in using entomopathogenic fungi for pest control because of the close pathogen $\times$ host relationship and because genetic variability is among the main factors affecting fungus pathogenesis on the host (Chouvenc et al., 2009; Xiao et al.,
2012). Thus, effective isolate selection in the laboratory improves the chances of success in the field.

Limited studies have used $B$. bassiana isolates to control P. latus, and these studies have primarily compared the effectiveness among different fungal species and not among isolates within the same species.

Penã et al. (1996) compared the mortality of P. latus using isolates of $B$. bassiana, Hirsutella thompsonii and Isaria fumosorosea and observed mortality of approximately $20 \%$ on the 2 nd day and $70 \%$ by the 6 th day.

The duration of $P$. latus female immature phases (from egg to adult) is approximately four days, and females begin oviposition at five days old, laying 5.6 eggs/day over ten days (Vieira and Chiavegato, 1998a, b). Thus, the mortality results for Unioeste 53 at six DAA (74\%) correspond to just over half of the female lifespan and demonstrate that the isolate can greatly impact the development of the next mite generation by preventing large numbers of nymphs from reaching adulthood and preventing or reducing oviposition.

Table 2. Percent of confirmed mortality of Polyphagotarsonemus latus adult females sprayed with 1 $\times 10^{8}$ conidia/mL suspension of different Beauveria spp. isolates at 3 DAA.

\begin{tabular}{cc}
\hline Treatment & Confirmed mortality \\
\hline Unioeste 53 & $33.5 \pm 2.17 \mathrm{a}$ \\
Unioeste 39 & $26.6 \pm 1.46 \mathrm{~b}$ \\
Unioeste 26 & $19.8 \pm 0.95 \mathrm{c}$ \\
$\mathrm{CV}=9.16 \%$ & \\
\hline
\end{tabular}

$\mathrm{DAA}=$ days after application; $\mathrm{CV}=$ coefficient of variance; SEM $=$ standard error of the mean; mean values $( \pm$ SEM $)$ followed by the same letter in the column do not differ in terms of Tukey test $(\mathrm{p}>0.05)$.

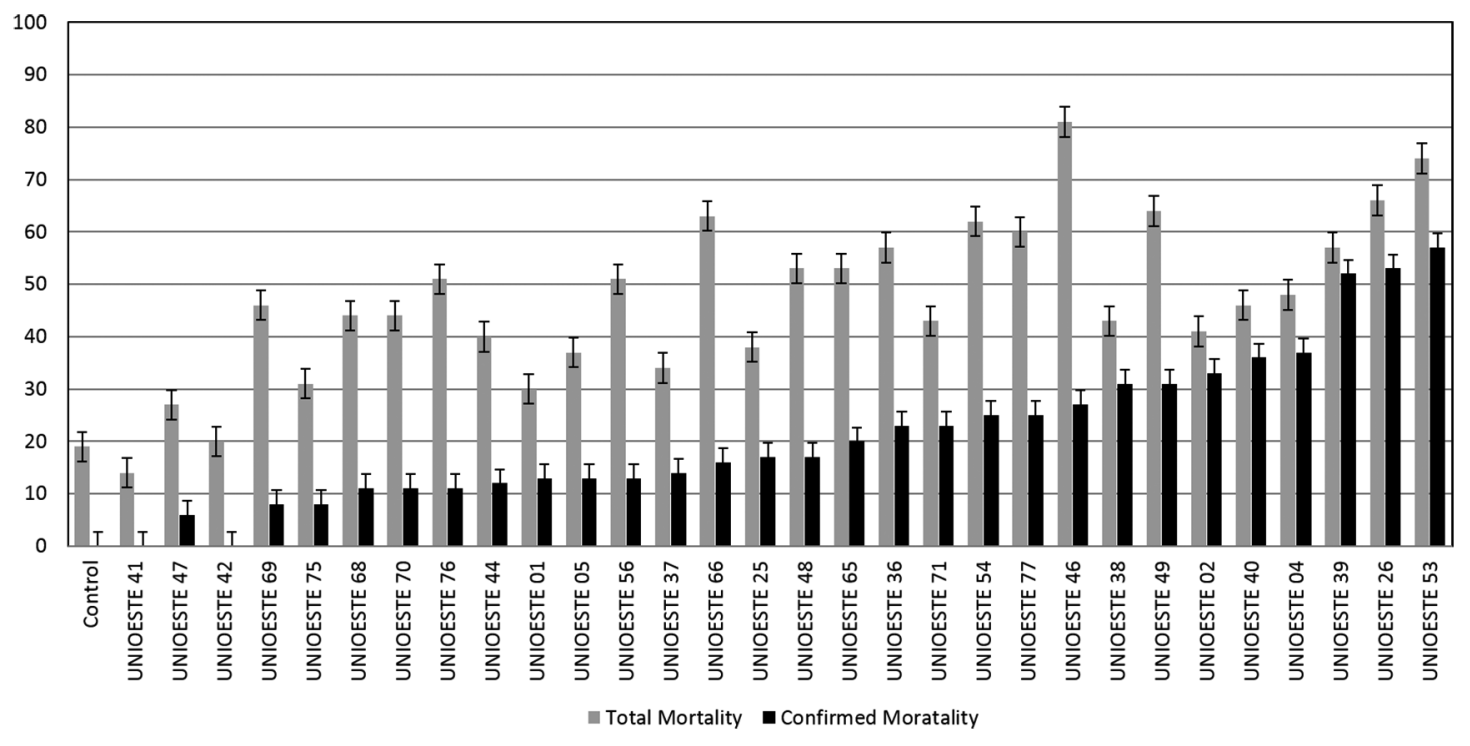

Figure 1. Percent total and confirmed mortality of Polyphagotarsonemus latus adult females at 6 DAA using Beauveria spp. conidial suspension at a $1 \times 10^{8}$ conidia/mL concentration. 
Despite differences in the percentage values, Penã et al. (1996) observed results similar to those of this study, in which confirmed mortality values of $33 \%$ and $57.7 \%$ were found for Unioeste 53 isolates at 3 and 6 DAA, respectively.

Nugroho and Ibrahim (2004) also tested B. bassiana, Metarhizium anisopliae and I. fumosorosea against P. latus; these researchers found that B. bassiana caused the highest mortality rate $(80.9 \%$ at a concentration of $1 \times 10^{8}$ conidia $/ \mathrm{mL}$ ) and observed large variation in the mortality caused among its isolates, which is consistent with the results presented here.

Differences in mortality observed in this study could be linked to genetic variation, which results in differences in the ability to produce enzymes, such as proteases and chitinases; cell growth mediators; cuticle-degrading fatty acids; certain hydrophobins that are extremely important for adhesion, infection and pathogenicity to the host; and compounds used as immunosuppressors and toxins, such as beauvericin, which contributes to suppressing the host immune system as well as inhibiting the growth of opportunistic microorganisms (Von Döhren, 2004; Valencia et al., 2011; Xiao et al., 2012).

Additionally, Chouvenc et al. (2009) demonstrated that the host defense system in other arthropods is effective in suppressing fungal infection and can affect fungal action. Moreover, the authors also observed a higher efficiency of the isolates in terms of reduced time to complete the infection cycle (adhesion to the host and colonization and death of the host), which explains variations between isolates.

These results indicate the importance of selecting isolates that have a high ability to kill the host in the shortest time possible and highlight the importance of performing isolate screening for virulence.

\subsection{Vegetative growth and conidial production}

A comparison of the parameters for growth and conidial production showed that the Unioeste 26 and 39 isolates had average diameters of 1.8 and $2.6 \mathrm{~cm}$, respectively. The Unioeste 53 isolate had an intermediate diameter of up to an average of $2 \mathrm{~cm}$ (Table 3 ). These values are lower than but close to those found in other studies in which colony diameters ranged from 2.9 to $4.5 \mathrm{~cm}$ (Potrich et al., 2006; Rohde et al., 2006).

These differences were primarily caused by the distinct isolates investigated in these studies, and because this fungus has a broad spectrum of hosts and large genetic plasticity, physiological variations can be expected among isolates because of their different nutritional requirements. Methodological differences may also have affected the outcomes because the reported incubation times varied between seven and ten days.

Different levels of vegetative growth were reported by Potrich et al. (2006) and Rohde et al. (2006) at $4.8 \times 10^{8}$ and $33.5 \times 10^{8}$ conidia/colony production, respectively. A conidia/colony production of $26.2 \times 10^{8}$ was observed for the Unioeste 53 isolate (Table 3 ) in the present study, which was in between the values reported in the aforementioned studies.

The Unioeste 53 isolate also exhibited a very high production of up to $7.9 \times 10^{8} \mathrm{conidia} / \mathrm{cm}^{2}$. In the previously cited studies, the highest observed values were approximately $3.0 \times 10^{8}$, showing that colony size is not correlated with conidial production.

Conidial production on rice was higher with the Unioeste 26 isolate $\left(3.1 \times 10^{9}\right.$ conidia/g rice $)$, whereas the Unioeste 53 and 39 isolates were similar $\left(1.6 \times 10^{9}\right.$ and $1.7 \times 10^{9}$ conidia/g rice, respectively) (Table 3).

It is difficult to compare the production rates on rice observed here to those reported for other studies because a culture medium cannot be standardized because of differences in the origin of the rice, group or even harvest, and these effects can manifest in the nutritional quality of the substrate. Nevertheless, the production rates of the Unioeste 53 isolate were similar to those reported in other studies and were even higher in some cases (Londono et al., 1992; Vilas Boas et al., 1996; Potrich et al., 2006; Rohde et al., 2006).

Although the Unioeste 53 isolate was not the most productive on rice, it was chosen for the subsequent tests in the greenhouse and field because of the results for the overall mortality parameters that were evaluated as well as the characterization of the selected isolates, which are important factors for mass production (Petlamul and Prasertsan, 2012).

\subsection{Greenhouse experiment}

Prior to the fungal application, the mite population on the control plants was 11 mites/leaf, and this value remained statistically unchanged until the 3rd evaluation (12 DAA), when the mite population reached 17.3 mites/leaf and remained constant until the final evaluation. The population grew by $64 \%$ on the control plants from pre-application to the last evaluation at 16 DAA (Table 4).

Table 3. Vegetative growth (colony diameter) and conidial production for different $B$. bassiana isolates in sporulation medium (SM) and rice.

\begin{tabular}{|c|c|c|c|c|}
\hline Isolate & $\begin{array}{l}\text { Mean colony } \\
\text { diameter }(\mathrm{cm})\end{array}$ & $\begin{array}{c}\text { Conidial production } \\
\text { /colony }\end{array}$ & $\begin{array}{c}{ }^{1} \text { Conidial } \\
\text { production } / \mathrm{cm}^{2}\end{array}$ & ${ }^{2}$ Production in rice \\
\hline Unioeste 39 & $2.6 \pm 0.07 \mathrm{a}$ & $2.33 \pm 0.35 b$ & $0.4 \pm 0.06 \mathrm{~b}$ & $1.7 \pm 3.38 \mathrm{~b}$ \\
\hline Unioeste 53 & $2.0 \pm 0.02 \mathrm{~b}$ & $26.2 \pm 4.44 \mathrm{a}$ & $7.9 \pm 1.43 \mathrm{a}$ & $1.6 \pm 2.95 b$ \\
\hline Unioeste 26 & $1.8 \pm 0.09 \mathrm{~b}$ & $0.2 \pm 0.01 \mathrm{c}$ & $0.1 \pm 0.00 \mathrm{c}$ & $3.1 \pm 2.15 \mathrm{a}$ \\
\hline
\end{tabular}

${ }^{1}$ mean number of conidia per $\mathrm{cm}^{2} \times 10^{8} ;{ }^{2}$ mean number of conidia per g rice $\times 10^{9}$; mean values $( \pm \mathrm{SEM})$ followed by the same letter in each column do not differ in terms of the Kruskal-Wallis test and the Student-Newman-Keuls comparison $(\mathrm{p}<0.05)$. 
Table 4. Mean number of live Polyphagotarsonemus latus mites on untreated bean leaves and bean leaves that are treated with a conidial suspension of the Unioeste 53 isolate $\left(1 \times 10^{8}\right.$ conidia/mL) in the greenhouse (Cascavel, PR, January to March 2014).

\begin{tabular}{cccccc}
\hline Treatments & $\begin{array}{c}\text { Pre- } \\
\text { application }\end{array}$ & Evaluation 1 & Evaluation 2 & Evaluation 3 & Evaluation 4 \\
\hline Control & $11.0 \pm 0.54 \mathrm{Bb}$ & $12.9 \pm 0.31 \mathrm{Ab}(+17)$ & $11.4 \pm 1.01 \mathrm{Ab}(+4)$ & $17.3 \pm 0.58 \mathrm{Aa}(+57)$ & $18.1 \pm 0.49 \mathrm{Aa}(+64)$ \\
Unioeste 53 & $13.2 \pm 0.59 \mathrm{Aa}$ & $9.2 \pm 0.30 \mathrm{Bb}(-31)$ & $4.9 \pm 0.31 \mathrm{Bc}(-62)$ & $4.3 \pm 0.40 \mathrm{Bc}(-67)$ & $4.2 \pm 0.37 \mathrm{Bc}(-68)$ \\
$\mathrm{CV} 1=11.28 \%$ & & & & & \\
$\mathrm{CV} 2=11.11 \%$ & & & & & \\
\hline
\end{tabular}

$\mathrm{CV}=$ coefficient of variation; $\mathrm{SEM}=$ standard error of the mean; $+=$ percent population increase, $-=$ percent population decrease compared with the pre-application population; mean values $( \pm$ SEM) followed by the same upper-case letter in a column and the same lower-case letter in a row are not different in terms of Tukey test $(\mathrm{p}<0.05)$.

In contrast, the initial population in the treated plants of 13.2 mites/leaf was significantly lower than that for the control plants at the 1 st evaluation (4 DAA) at 9.2 mites/leaf. In the 2 nd evaluation ( $8 \mathrm{DAA})$, the population was reduced even further to less than five mites/leaf and remained at this level until the last evaluation (16 DAA). The population decreased by $68.12 \%$ between the pre-application and the final evaluation (16 DAA). The mite population in the treated plants with the fungus was statistically lower than that found in the control plants for all evaluations that were performed after the fungal application (Table 4).

At 8 DAA, the mite population was reduced by approximately $62 \%$ and by $68.12 \%$ at 16 DAA, which was consistent with the results reported by Penã et al. (1996) in which the $P$. latus population was reduced by $88 \%$ at 12 DAA in a greenhouse experiment using $B$. bassiana isolates.

Ashraf et al. (2011) observed a reduction of $87.8 \%$ in the broad mite population at 5 DAA using B. bassiana, demonstrating more rapid action by the isolate than in the present study, where the reduction was $31 \%$ at 4 DAA. However, in subsequent evaluations (7,10 and 17 DAA), the same authors obtained mean population reductions of $59.89,42.30$ and $0.00 \%$, respectively. In this study, however, the population reduction at 8,12 and 16 DAA was 62,67 and $68 \%$, respectively, indicating that the action of the isolate Unioeste 53 was more persistent although slower than that of other B. bassiana isolates.

Despite the variation observed between the results of the present study and relevant studies available in the literature caused by differences in the experimental conditions (ambient conditions, such as daily temperature conditions of $22 \pm 3{ }^{\circ} \mathrm{C}$ and relative humidity of $84 \pm 10 \%$; host plant species; and isolate and conidial concentrations, among others), the fungus applied in this study maintained a low mite population throughout the experiment, which demonstrates the potential of the Unioeste 53 isolate to control this pest.

\subsection{Field experiment}

The initial mite population at pre-application was homogeneous, and significant differences were not observed in the initial number of mites between plants.

The control mite population remained constant throughout the experiment and did not exhibit significant changes compared with the mite population in the plants that were treated with the fungus. The action of the fungus on the mite population resulted in significant variations of the treated populations, with the mite population gradually decreasing up to 12 DAA and increasing significantly at 16 DAA. However, these populations remained below the population size at pre-application, and mycosed mites were not observed on treated plants.

Significant differences in size were not observed between mite population in the untreated plants and those treated with fungus at each evaluation; however, the efficiency of the fungal treatment, which was obtained using Henderson-Tilton's formula, gradually increased over time from $28 \%$ after 4 DAA to a maximum value of $69 \%$ at 12 DAA and then decreasing to $49 \%$ at 16 DAA (Table 5).

Compared with the pre-application values, the fungal application resulted in a population reduction of approximately $26 \%$ at $4 \mathrm{DAA}$, whereas the population in the control remained virtually unchanged. In the 2 nd evaluation at $8 \mathrm{DAA}$, the fungal application resulted in a population reduction of $47 \%$ compared with a reduction of only $6 \%$ in the control. In the 3 rd evaluation at 12 DAA, the population decreased by $67 \%$ for the treated plants and increased by $4 \%$ in the control. However, in the final evaluation at $16 \mathrm{DAA}$, the population increased from that at $12 \mathrm{DAA}$, and the final population in the treated plants was $42 \%$ lower than the pre-application population in the treated plants; however, the final population exceeded the initial population by $10 \%$ in the control (Table 5 ).

In this pioneering study to assess the control of $P$. latus using pathogenic fungi under field conditions, pathogen efficiency was moderate compared with that of chemical acaricides, and the use of abamectin, multimethyl alkenol and dicofol in cotton reduced the mite population by up to $94 \%$ at 13 DAA or $90 \%$ at 14 days after Pyridathioben ${ }^{\circledR}$ and Cascade application (Silva et al., 1989).

Chemicals are immediately effective on hosts because the majority of chemicals act directly on the nervous system and cause motor activity to cease almost immediately, which affects the physiological functions of the hosts and causes death (Coutinho et al., 2005). In contrast, fungi require a longer time to develop and kill the host. However, according to the concept of augmentative biological control, successive applications of a fungus contribute to an 
Table 5. Mean number per treatment of live Polyphagotarsonemus latus mites on untreated bean leaves and bean leaves that are treated with a suspension of conidia from the Unioeste 53 isolate $\left(1 \times 10^{8}\right.$ conidia $\left./ \mathrm{mL}\right)$ in the field (Marechal Cândido Rondon, PR, January to March 2014).

\begin{tabular}{cccccc}
\hline & Pre-application & $\begin{array}{c}\text { Evaluation 1 } \\
\text { (4 DAA) }\end{array}$ & $\begin{array}{c}\text { Evaluation 2 } \\
\text { (8 DAA) }\end{array}$ & $\begin{array}{c}\text { Evaluation 3 } \\
\text { (12 DAA) }\end{array}$ & $\begin{array}{c}\text { Evaluation 4 } \\
\text { (16 DAA) }\end{array}$ \\
\hline Control & $16.1 \pm 2.54 \mathrm{Aa}$ & $16.3 \pm 1.85 \mathrm{Aa}(+1)$ & $15.5 \pm 1.08 \mathrm{Aa}(-7)$ & $16.8 \pm 0.64 \mathrm{Aa}(+4)$ & $17.7 \pm 1.05 \mathrm{Aa}(+10)$ \\
Unioeste 53 & $29.8 \pm 5.80 \mathrm{Aa}$ & $22.0 \pm 3.08 \mathrm{Ab}(-26)$ & $15.8 \pm 2.47 \mathrm{Ab}(-47)$ & $9.9 \pm 0.92 \mathrm{Ac}(-67)$ & $17.0 \pm 0.81 \mathrm{Ab}(-42)$ \\
Efficiency (\%) & - & 28 & 45 & 69 & 49 \\
\hline
\end{tabular}

$+=$ percent population increase, $-=$ percent population decrease compared with the pre-application population; means $( \pm$ SEM) followed by the same upper-case letter in each column are not different in terms of the Wilcoxon test $(\mathrm{p}<0.05)$; mean values $( \pm$ SEM) followed by the same lower-case letter in each row are not different in terms of the Friedman test $(p<0.05)$. Efficiency $\%=$ percent efficiency over time (per evaluation) calculated using Henderson-Tilton's formula.

increased inoculum potential in the environment, thereby increasing the effectiveness of fungi over time (Alves et al., 2008). Nevertheless, sequential applications of chemicals promote selective resistance among populations, which increases the difficulty of pest control.

Furthermore, chemical acaricides are not allowed for all of the crops in which mites occur (BRASIL, 2012). $P$. latus is a polyphagous species; thus, entomopathogenic fungi are important for the control of this pest because there are no restrictions on the use of these fungi in crops for which chemical use is not allowed, including organic crops (Gallo et al., 2002), although fungal biocontrol products must be registered for such crops.

The $41.4 \%$ efficiency achieved in the 3 rd evaluation shows the potential of the fungus to control the mite, and this efficiency could be increased by reapplication according to the incremental biological control concept developed by Alves (1998) and Alves et al. (2008). Compared with the effects of chemical acaricides, the effectiveness of the biological control of mites is increased by predatory mites, which are not affected by the fungus and thus are preserved in the agro-ecosystem (Cavalcanti et al., 2008).

In addition, under greenhouse and field conditions, the $P$. latus population size after application always remained below the original size before the fungal treatment, whereas in the control group, the population increased over time. These results demonstrate the isolate's potential for control, especially under greenhouse conditions, where P. latus is a major cause of damage to many crops.

Because of the absence of studies testing entomopathogenic fungi control of $P$. latus under field conditions, the results of the present study can be used to advance research on mite control and promote pest control alternatives to mitigate the negative impacts to crop production or natural resources and the health of farmers and consumers. However, additional studies are necessary to evaluate the effectiveness of the fungus in reapplications, which may increase fungal populations in the environment as an augmentative pest control technique.

\section{References}

ALVES, L.F.A., QUEIROZ, D.L. and ANDRADE, D.P., 2010. Damage characterization and control tactics to broad mite (Polyphagotarsonemus latus Banks), in Paraguay-tea plants (Ilex paraguariensis St. Hill.). Revista Brasileira de Biociências, vol. 8, pp. 208-212

ALVES, R.T. and FARIA, M., 2010. Pequeno manual sobre fungos entomopatogênicos. Planaltina: Embrapa Cerrados. 50 p.

ALVES, S.B., 1998. Fungos entomopatogênicos. In: S.B. ALVES, ed. Controle microbiano de insetos. 2nd ed. Piracicaba: FEALQ. $1163 \mathrm{p}$

ALVES, S.B., ALMEIDA, J.E.M., MOINO JUNIOR, A. and ALVES, L.F.A., 1998. Técnicas de laboratório. In: S.B. ALVES, ed. Controle microbiano de insetos. 2nd ed. Piracicaba: FEALQ. $1163 \mathrm{p}$.

ALVES, S.B., LOPES, R.B., VIEIRA, A.S. and TAMAI, M.A., 2008. Fungos entomopatogênicos usados no controle de pragas na América Latina. In: S.B. ALVES and R.B. LOPES eds. Controle microbiano de pragas na América Latina. Piracicaba: FEALQ. vol. $14,414 \mathrm{p}$.

ASHRAF, A.M., AHMED, M.T., HANAFY,A.R.I. and GAMAL, M.H., 2011. Biology and control of the broad mite Polyphagotarsonemus latus (Banks, 1904) (Acari: Tarsonemidae). International Journal of Environmental Science and Engineering., vol. 1, pp. 26-34.

BAKR, E. 2002 [viewed 18 September 2014]. Control correction [online]. Available from: http://www.ehabsoft.com/ldpline/ onlinecontrol.htm

BRASIL. Ministério da Agricultura, Pecuária e Abastecimento - MAPA, 2012 [viewed 15 August 2012]. Agrofit: sistemas de agrotóxicos fitossanitários [online]. Brasília: MAPA. Available from: http://extranet.agricultura.gov.br/agrofit_cons/principal_agrofit_cons

CAVALCANTI, R.S., REIS, P.R., JUNIOR, A.M., FALQUETO, R., FRANCO, R.A. and CARVALHO, T.M.B., 2008. Patogenicidade de fungos entomopatogênicos a três species de ácaros em cafeeiro. Coffee Science, vol. 3, pp. 68-75.

CHOUVENC, T., SU, N.Y. and ROBERT, A., 2009. Cellular encapsulation in the eastern subterranean termite, Reticulitermes flavipes (Isoptera), against infection by the entomopathogenic fungus Metarhizium anisopliae. Journal of Invertebrate Pathology, vol. 101, no. 3, pp. 234-241. http://dx.doi.org/10.1016/j.jip.2009.05.008. PMid: 19463828

COUTINHO, C.F.B., TAMINOTO, S.T., GALLI, A., GARBRLLINI, G.S., TAKAYAMA, M., DO AMARAL, R.B., MAZO, L.H., AVACA, L.A. and MACHADO, S.A.S., 2005. Pesticidas: Mecanismos de ação, degradação e toxidez. Revista de Ecotoxicologia e Meio Ambiente, vol. 15, pp. 62-75.

ECHER, M.M., FERNANDES, M.C.A., RIBEIRO, R.L.D. and PERACCHI, A.L., 2002. Avaliação de genótipos de Capsicum para 
resistência ao ácaro branco. Horticultura Brasileira, vol. 20, no. 2, pp. 217-221. http://dx.doi.org/10.1590/S0102-05362002000200020.

\section{EMPRESA DE ASSISTÊNCIA TÉCNICA E EXTENSÃO RURAL} - EMATER, 2000 [viewed 5 February 2013]. Cultura do Feijão [online]. Minas Gerais. pp. 1-7. Available from: http://www. almanaquedocampo.com.br/imagens/files /feij\%C3\%A3o\%20 emater.pdf.

GALLO, D., NAKANO, O., SILVEIRA NETO, S., CARVALHO, R.P.L., BATISTA, G.C., BERTI FILHO, E., PARRA, J.R.P., ZUCCHI, R.A., ALVES, S.B., VENDRAMIN, J.D., MARCHINI, L.C., LOPES, J.R.S. and OMOTO, C., 2002. Entomologia Agrícola. Piracicaba, FEALQ. 920 p.

HAJEK, A.E. and ST. LEGER R.J., 1994. Interactions between fungal pathogens and insect hosts. Annual Review of Entomology, vol. 39, pp. 293-322. http://dx.doi.org/10.1146/annurev. en.39.010194.001453.

HUMBER, R.A., 1997. Fungi: identification. In: L.A. LACEY, ed. Manual of techniques in insect pathology. Cambridge: Academic Press, pp. 153-185.

LONDONO, O.P.A., FLOREZ, F.J.P., PARDEY, E.A.B. and GARCIA, M.T.G., 1992. Production en finca del hongo Beauveria bassiana para el control de la broca del café. Cenicafé: Avances Tecnicos, vol. 182, pp. 11

MORAES, G.J. and FLECHTMANN, C.H.W., 2008. Manual de Acarologia: Acarologia básica éácaros de plantas cultivadas no Brasil. Ribeirão Preto: Holos. 308 p.

NUGROHO, I. and IBRAHIM, Y.B., 2004. Bioassay of some entomopathogenic fungi against broad mite (Polyphagotarsonemus latus Banks). International Journal of Agriculture and Biology, vol. 6 , pp. 223-225.

NUGROHO, I. and IBRAHIM, Y.B., 2007. Efficacy of laboratory prepared wettable powder formulation of entomopathogenous fungi Beauveria bassiana, Metarhizium anisopliae and Paecilomyces fumosoroseus against the Polyphagotarsonemus latus (Bank) (Acari: Tarsonemidae) (broad mite) on Capsicum annum (chilli). Journal of Biosains, vol. 18, pp. 1-11.

OLIVEIRA, D.G.P., 2009. A protocol for assessing the viability of entomopathogenic fungal conidia and the determination of heat protection conferred to Beauveria bassiana and Metarhizium anisopliae by an emulsifiable oil formulation. Piracicaba: Universidade de São Paulo, Escola Superior de Agricultura Luiz de Queiroz, 89 p. Master's Dissertation in Science.

OLIVEIRA, R.C., NEVES, P.M.O.J. and ALVES, L.F.A., 2004. Seleção de Fungos Entomopatogênicos para o controle de Oligonychus yothersi (McGregor) (Acari: Tetranychidae), na cultura da erva-mate (Ilex paraguariensis St. Hill.). Neotropical Entomology, vol. 33, no. 3, pp. 347-351. http://dx.doi.org/10.1590/ S1519-566X2004000300012.

PEÑA, J.E., OSBORNE, L.S. and DUNCAN, R.E., 1996. Potential of fungi as biocontrol agents of Polyphagotarsonemus latus. Entomophaga, vol. 41, no. 1, pp. 27-36. http://dx.doi. org/10.1007/BF02893289.

PETLAMUL, W. and PRASERTSAN, P., 2012. Evaluation of strains of Metarhizium anisopliae and Beauveria bassiana against Spodoptera litura on the basis of their virulence, germination rate, conidia production, radial growth and enzyme activity. Mycobiology, vol. 40, no. 2, pp. 111-116.
POTRICH, M., ALVES, L.F.A., MERTZ, N.R. and SILVA, E.R.L., 2006. Avaliação de Beauveria bassiana (Bals.) Vuill. e Metarhizium anisopliae (Metsch.) Sorok. para Controle de Sitophilus zeamais (Coleoptera: Curculionidae) BioAssay, vol. 12, pp. 1-9.

ROHDE, C., ALVES, L.F.A., NEVES, P.M.O.J., ALVES, S.B., SILVA, E.R.L. and ALMEIDA, J.E.M., 2006. Seleção de isolados de Beauveria bassiana (Bals.) Vuill. e Metarhizium anisopliae (Metsch.) Sorok. contra o cascudinho Alphitobius diaperinus (Panzer) (Coleoptera: Tenebrionidae). Neotropical Entomology, vol. 35, no. 2, pp. 231-240. http://dx.doi.org/10.1590/S1519566X2006000200012.

SARMENTO, R.A., RODRIGUES, D.M., FARAJI, F., ERASMO, E.A., LEMOS, F., TEODORO, A., KIKUCHI, W.T., DOS SANTOS, G.R. and PALLINI, A., 2011. Suitability of the predatory mites Iphiseiodes zuluaga and Euseius concordis in controlling Polyphagotarsonemus latus and Tetranychus bastosi on Jatropha curcas plants in Brazil. Experimental \& Applied Acarology, vol. 53, no. 3, pp. 203-214. http://dx.doi.org/10.1007/s10493-0109396-2. PMid:20844929.

SILVAA.L.; VELOSO V.R.S.; GOMES M.A.N. and ROCHA M.R., 1989. Controle químico do ácaro branco Polyphagotarsonemus latus (Banks, 1904) (Acari: Tarsonemidae) em algodoeiro. Anais da Escola Agronômica e Veterinária, vol. 19, pp. 17-21.

UNIVERSIDADE ESTADUAL DO OESTE DO PARANÁ UNIOESTE, 2014 [viewed 29 October 2014]. CFEUnioeste: Coleção de Fungos Entomopatogênicos do Laboratório de Biotecnologia Agrícola [online]. Cascavel. Available from: http://splink.cria.org.br/manager/detail?resource=CFEUnioeste

VALENCIA, J.W.A., BUSTAMANTE, A.L.G., JIMÉNEZ, A.V. and GROSSI-DE-SÁ, M.F., 2011. Cytotoxic activity of fungal metabolites from the pathogenic fungus Beauveria bassiana: an intraspecific evaluation of Beauvericin production. Current Microbiology, vol. 63, no. 3, pp. 306-312. http://dx.doi.org/10.1007/ s00284-011-9977-2. PMid:21761220.

VIEIRA, M.R. and CHIAVEGATO, L.G., 1998a. Biologia de Polyphagotarsonemus latus (Banks, 1904) (Acari: Tarsonemidae) em algodoeiro. Pesquisa Agropecuaria Brasileira, vol. 33, pp. 1437-1432.

VIEIRA, M.R. and CHIAVEGATO, L.G., 1998b. Biologia de Polyphagotarsonemus latus (Banks) (Acari: Tarsonemidae) em limão siciliano (Citrus limon Burm). Neotropical Entomology, vol. 28 , pp. 27-33.

VILAS BOAS, A.M., ANDRADE, R.M. and OLIVEIRA, J.V., 1996. Diversificação de meios de cultura para produção de fungos entomopatogênicos. Journal of Invertebrate Pathology, vol. 39, pp. 123-128.

VON DOHREN, H., 2004. Biochemistry and general genetics of nonribosomal peptide synthetases in fungi. Advances in Biochemical Engineering/Biotechnology, vol. 88, pp. 217-264. http://dx.doi.org/10.1007/b99262. PMid:15719557.

XIAO, G., YING, S.H., ZHENG, P., WANG, Z.L., ZHANG, S., XIE, X.Q., SHANG, Y., LEGER, R.J.S.T., ZHAO, G.P., WANG, C. and FENG, M.G., 2012. Genomic perspectives on the evolution of fungal entomopathogenicity in Beauveria bassiana. Scientific Reports, vol. 2, pp. 1-10. http://dx.doi.org/10.1038/srep00483. PMid:22761991. 